GROUND-WATER HYDROLOGY AND SUBSURFACE MIGRATION OF RADIOISOTOPES

AT A LOW-LEVEL SOLID RADIOACTIVE-WASTE DISPOSAL SITE, WEST VALLEY, NEW YORK

by David E. Prudic and Allan D. Randa11, $1432-$

Open-file Report 77-566

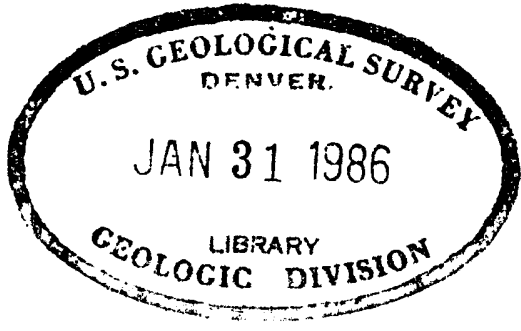

July 1977 
The following factors may be used to convert the International (metric) units of measurement in this report to conventional (English) units.

sII units

Multiply by

centimeters $(\mathrm{cm})$

kilometers $(\mathrm{km})$

meters (m)

millimeters (mn)

hectares (ha)
milliliters (mL)
liters (L)

$\underline{\text { Radiometric concentration }}$

microcuries per milliliter $(\mu \mathrm{Ci} / \mathrm{mL})$

microcuries per gram ( $\mu \mathrm{Ci} / \mathrm{gm})$

1/ International system of units centimeters per second

$(\mathrm{cm} / \mathrm{s})$

2835.
Hydraulic conductivity
Length

To.obtain English units

inches (in.)

miles (mi)

feet ( $\mathrm{ft}$ )

inches (in.)

\section{$\underline{\text { Area }}$}

0.468

acres

Volume

0.034

1.057

fluid ounces ( $f 1$ oz)

quarts (qt)

feet per day ( $f t / d)$
0.621

039 
Conversion factors and abbreviations......................1i

Abstract...........................................

Ground-water flow system...............................

Recharge to the trenches...............................

Subsurface migration of radioisotopes......................15

A provisional perspective on the hydrology................... 26

References cited..................................... 28

\section{ILLUSTRATIONS}

Figure 1. Map showing location of test holes near low-level radioactive-waste burial trenches................. 3

2. Summary of data for test hole G................... 4

3. Cross section through north trenches showing head distribution during February 1976................ 5

4. Cross section through south trenches showing head distribution February 1976..................... 6

5. Generalized cross section from east edge of burial site to Buttermilk Creek........................ 8

6. Water levels in trenches $2-11,1966-76 \ldots \ldots \ldots \ldots \ldots 10$

7. Graph showing changes in water level in trench 5 compared with precipitation, May-September 1975....... 12

8. Graph showing barometric efficiency compared with water-1evel altitude, trench 5, May to September 1975... 14

9-13. Graphs showing changes in tritium concentration with depth:

9. North of north trenches................... 17

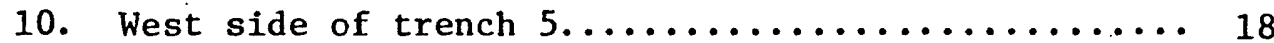

11. East side of trench $2 \ldots \ldots \ldots \ldots \ldots \ldots \ldots$

12. Vicinity of south trenches.................. 20

13. Outlying test holes........................ 21

14. Detailed cross sections through holes B, D, and E..... 23 
Table 1. Analyses for radioisotopes other than tritium in cores..................................... 24

2. Preliminary results of in-hole gamma spectral logging.... 25 


\title{
GROUND-WATER HYDROLOGY AND SUBSURFACE MIGRATION OF \\ RADIOISOTOPES AT A LOW-LEVEL SOLID RADIOACTIVE-WASTE DISPOSAL SITE, WEST VALLEY, NEW YORK
}

by

David E. Prudic and Allan D. Randall

\begin{abstract}
Burial trenches for disposal of solid radioactive waste at West Valley, N.Y. are excavated in till that has very low hydraulic conductivity (about $5 \times 10^{-8}$ centimeters per second). Fractures and root tubes with chemically oxidized and(or) reduced soil in their, walls extend 3 to 4.5 meters below natural land surface. Preliminary simulations of pressure heads with a digital model suggest that hydraulic conductivity is an order of magnitude greater in the fractured till near land surface than at greater depth. Hydraulic gradients are predominantly downward, even beneath small valleys. The upper part of a body of underlying lacustrine silt is unsaturated; in the lower, saturated part, slow lateral flow may occur.

In the older trenches, water began to build up in 1971 , overflowed briefly in 1975, and was pumped out in 1975-76. Water levels rose abruptly during major rainstorms in mid-1975, indicating rapid infiltration through cracks in the cover material. The new trenches have maintained low, stable water levels, perhaps because of thicker, more compact cover and less waste settlement; pressure heads near these trenches are low, locally approaching zero, perhaps because of slight infiltration and limited near-surface storage.

Peak tritium concentrations in test-hole cores (generally $10^{-5}$ to $10^{-3}$ microcuries per milliliter) were found within 3 meters of 1 and surface and are attributed to surface contamination. Concentrations declined rapidly with depth within the fractured till; secondary peaks found at about 9 meters in three holes are attributed to lateral migration from trenches. Other radioisotopes were detected only near land surface. Samples from the walls of shallow fractures revealed no accumulation of radioisotopes.
\end{abstract}


A companion paper (Pferd and others, in press) descibes the geologic setting of a low-level radioactive-waste burial ground covering 4 hectares near West Valley, N.Y. Geologic studies have shown that the burial ground is underlain by 27 meters of silty, clayey till incorporating severely deformed, discontinuous beds of silt to very fine sand and, rarely, coarser sand; these materials constitute about 7 percent of the till penetrated by test holes above a depth of 15 meters. Fractures and root tubes whose surfaces are bordered by firm, chemically oxidized till are recognizable to depths of 3 to 4.5 meters and provide secondary porosity.

Test holes drilled as part of the current investigation in 1975 and 1976 were designed to provide information about the flow of ground water as well as the geology. Cores were analyzed to determine the distribution of radioisotopes and thereby detect possible movement of water away from the burial trenches; piezometers were installed at various depths to determine head distribution in three dimensions. The locations of most test holes are shown in figure 1. Each of the 1975-76 test holes contains from one to four piezometers, which are set in sand envelopes about 45 centimeters thick and covered by at least 3 meters of cement grout. Data for a typical hole are summarized in figure 2.

The distribution of hydraulic head along cross sections perpendicular to the north (older) and south (newer) burial trenches in February 1976 is 1llustrated in figures 3 and 4, in which several features may be noted:

(1) The lowest part of the refuse was saturated in all trenches, and most of the north trenches were nearly filled with water. (Depth of water in the south trenches increased southward, reaching at least 1.5 meters near the south end of each trench, because trench floors slope in that direction. The origin of trench water is discussed in the following section, "Recharge to the Trenches.")

(2) Hydraulic gradients were predominantly downward, even beneath small valleys at the east and west ends of the cross section (fig. 3), where localized discharge of ground water might have been expected.

(3) In general, water was flowing outward and downward from the trenches. A small flow component toward trench 5 may be inferred from the head near land surface within 10 meters west of the trench, but otherwise no ground-water contribution to the trenches is indicated.

In eastern United States, unsaturated sediment is commonly limited to a narrow zone between land surface and a water table approximately parallel to land surface. Near the West Valley burial site, however, conditions are more complex. West of trench 14, piezometers between depths of 5.5 and 14 meters in holes L (figs. 1, 4) and Q. (fig. 1) have 


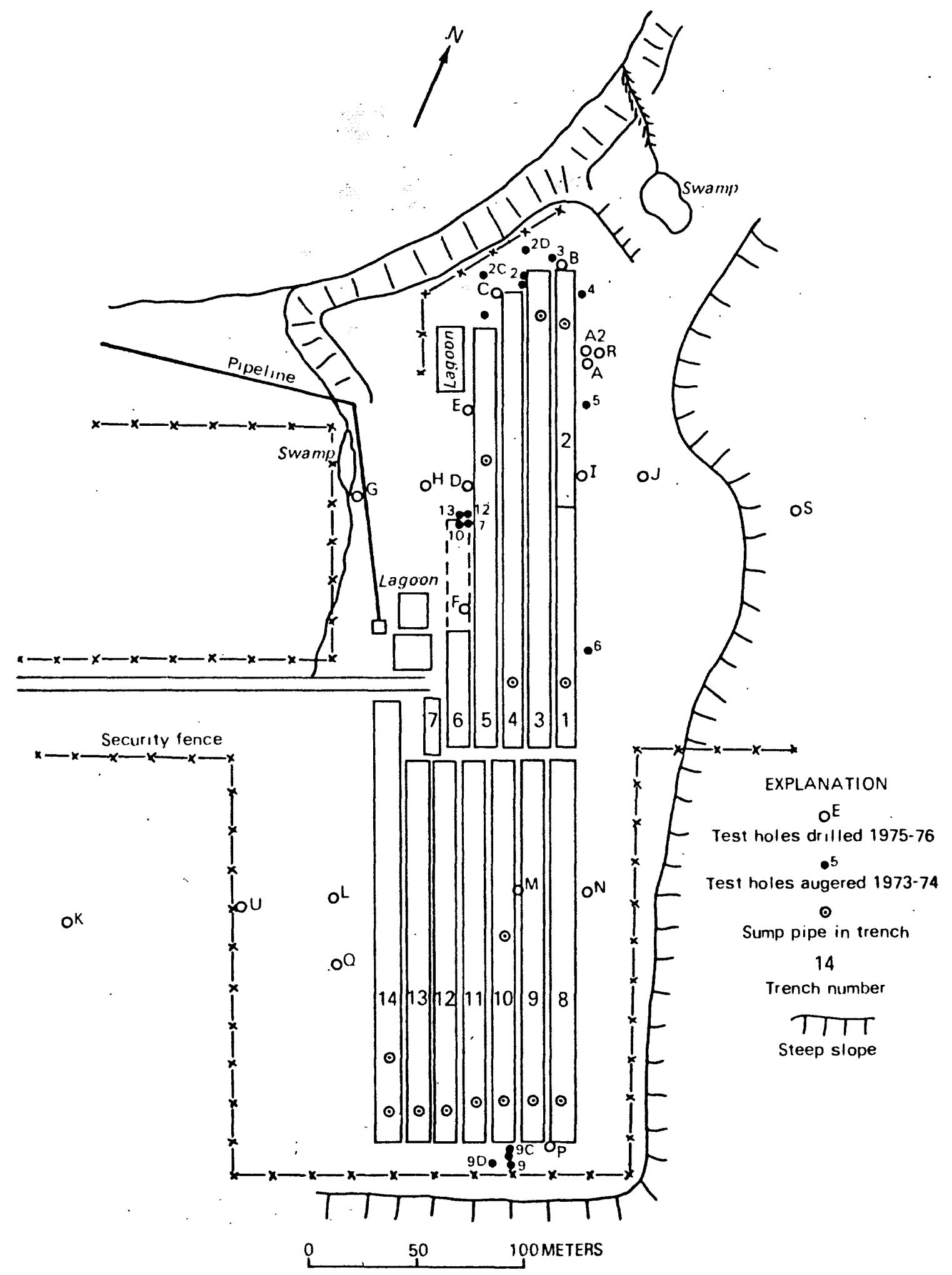

Figure 1.--Location of test holes near low-level radioactive-waste burial trenches. 


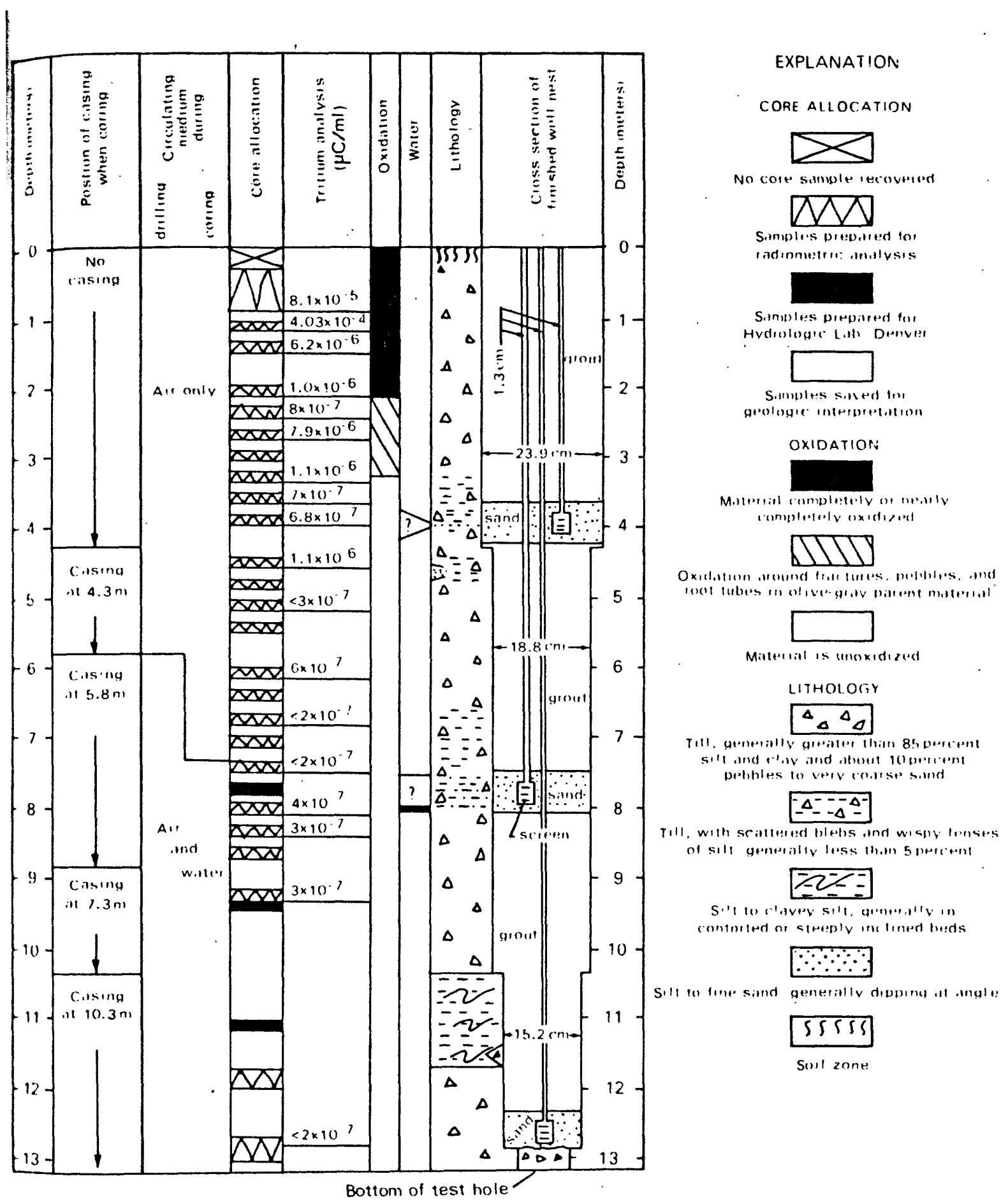

Figure 2.--Summary of data for test hole G. 


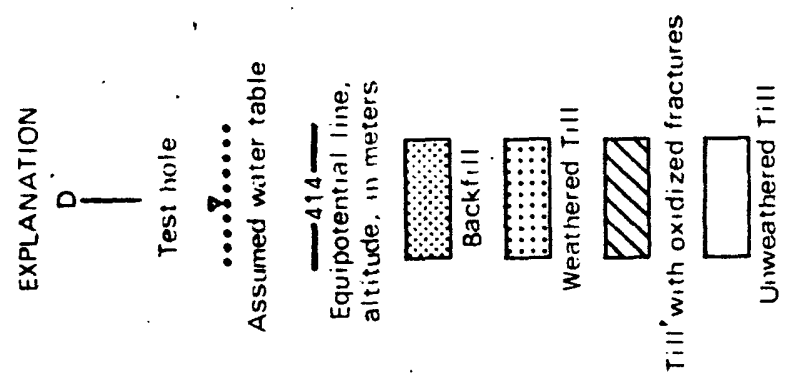

范

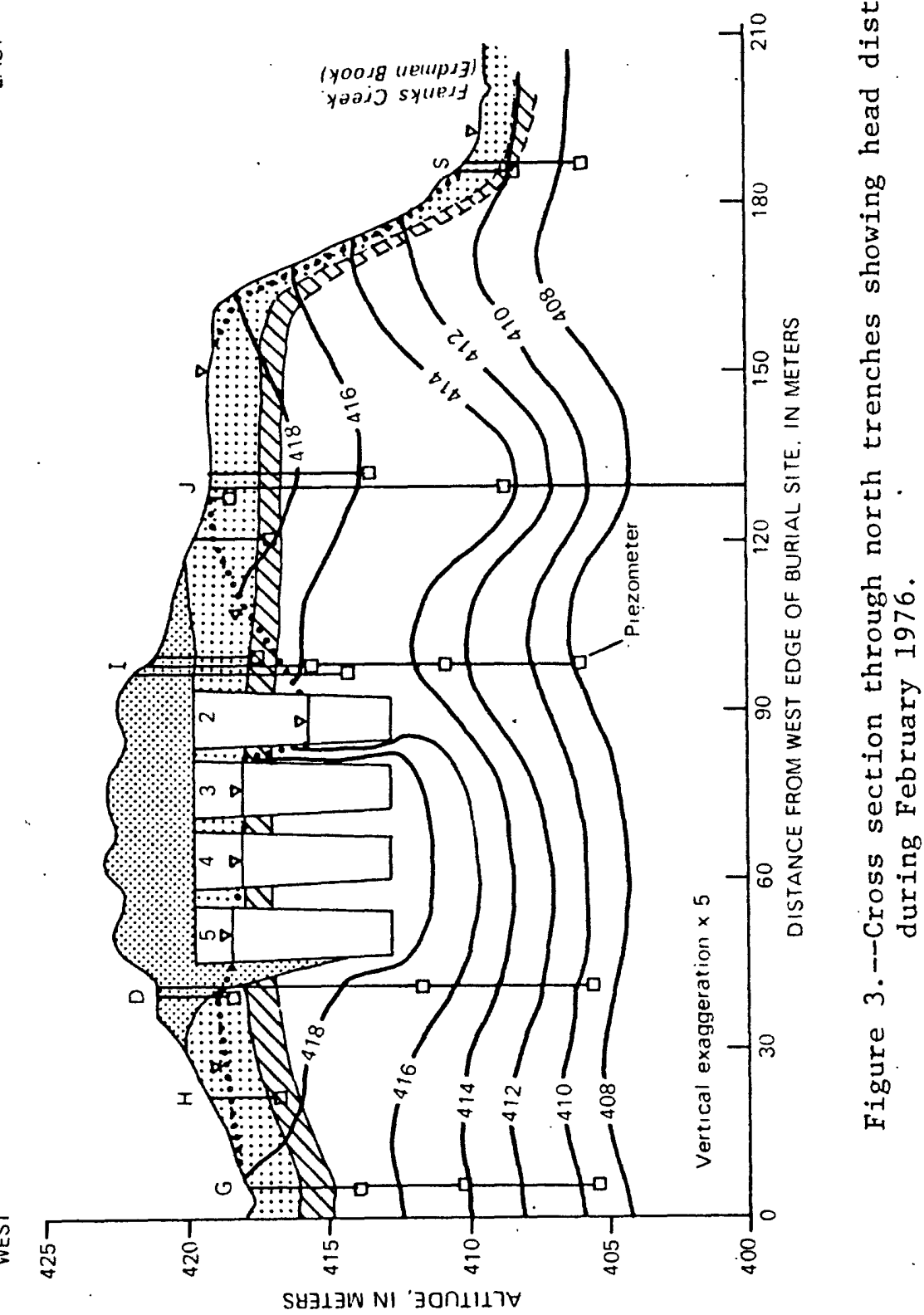




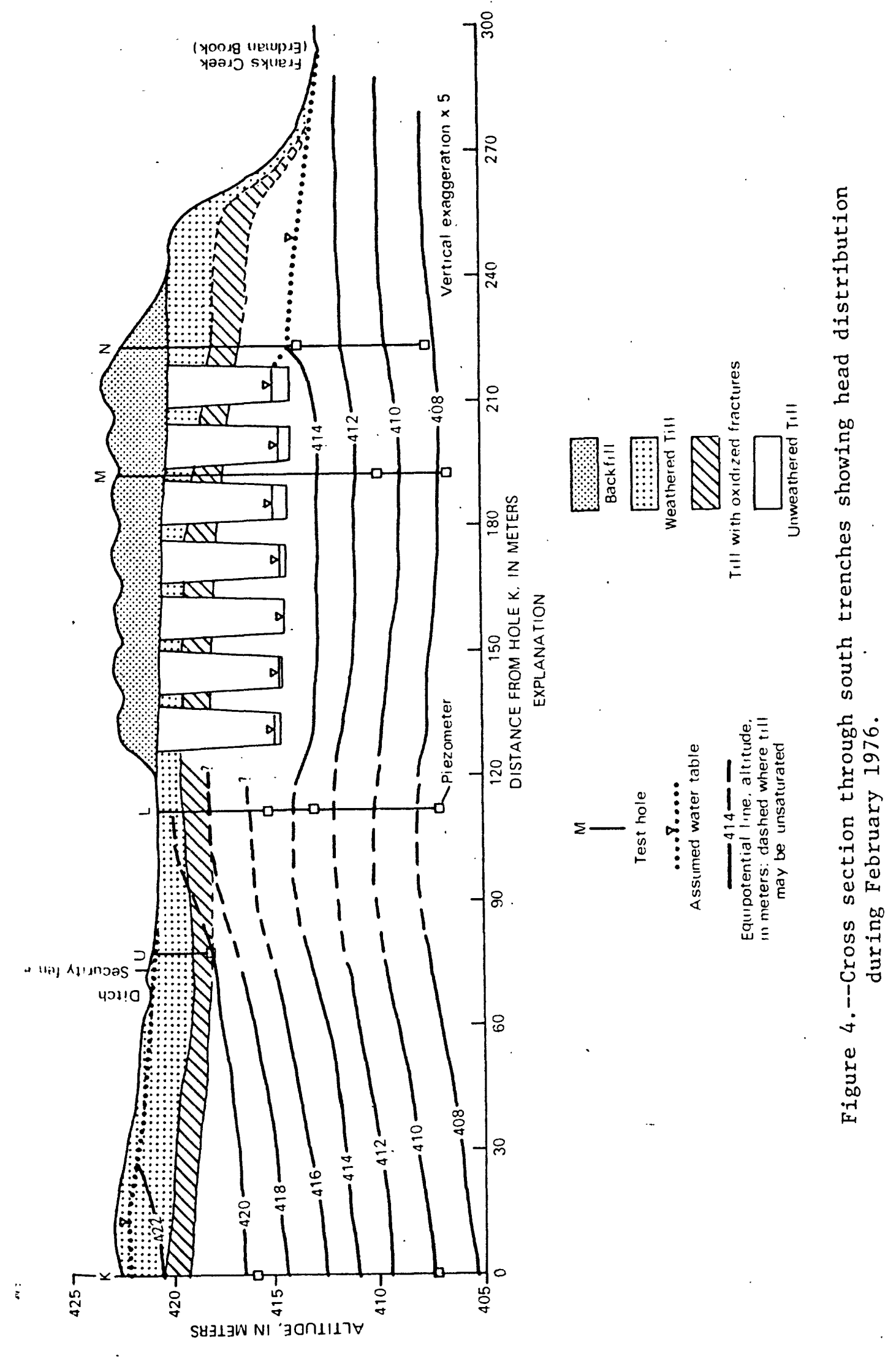


never contained water since their installation. Neutron moisture profiles showed 1ittle difference between moisture content in the till near hole $L$ and that in saturated till near hole $U$ (figs. 1, 4) which suggests that pressure head is very close to zero in the non-water-yielding till.

This interpretation is represented by the dashed contours in figure 4. The upper soil layers have been scraped away from the area between trench 14 and hole $U$, leaving an exceptionally smooth, sloping, bare surface that sheds nearly all rainfall; this may explain the absence of measurable positive heads at depth. Absence of positive pressure heads has also been observed in piezometers along the east side of the trenches, at depths of 8 meters at hole $\mathrm{N}$ and 4 to 6 meters at hole I (fig. 1); these holes are on relatively steep, smooth slopes that also shed water readily. Fresh excavations in till near the site intersected several small sand lenses whose upper parts were unsaturated, and at least one of the sand lenses penetrated by test holes was unsaturated.

The till in which the trenches are excavated is very poorly permeable. Horizontal hydraulic conductivity was calculated from slug tests of several piezometers by the method of Cooper and others (1967). Eight piezometers finished in unweathered till yielded values ranging from $9.3 \times 10^{-8}$ to $3.5 \times 10^{-8}$ centimeters per second $(\mathrm{cm} / \mathrm{s})$, and four piezometers finished next to distorted sand or silt lenses (partings) within the unweathered till yielded values ranging from $3 \times 10^{-6}$ to $4 \times 10^{-8} \mathrm{~cm} / \mathrm{s}$. The average horizontal hydraulic conductivity for unweathered till was about $5 \times 10^{-8}$ $\mathrm{cm} / \mathrm{s}$, and it is estimated that a weighted average including the distorted sand and silt partings would be about $1 \times 10^{-7} \mathrm{~cm} / \mathrm{s}$. As of May 1977, only one slug test from the weathered till $\left(1.3 \times 10^{-7} \mathrm{~cm} / \mathrm{s}\right)$ and one from the unweathered till with oxidized fractures $\left(5 \times 10^{-8} \mathrm{~cm} / \mathrm{s}\right)$ have been obtained.

Beneath the till in which the trenches are excavated is a sequence of layered silt and clay, locally grading upward into fine sand and silt and capped by grave1 (fig. 5). The upper, sandy part of this lacustrine sequence is unsaturated east and south of the burial site, and piezometers in the underlying saturated silt and clay suggest a small lateral gradient to the northeast toward Buttermilk Creek. No substantial springs have been detected where the lacustrine unit crops out along the steep valley walls of Buttermilk Creek. Therefore, ground-water discharge from this unit must be small enough to seep away without removing the deposits resulting from mudflow and soil creep that generally mantle the slope, or possibly may occur chiefly where the silt dips down to creek grade some distance to the north. It seems likely that water from the burial trenches, after seeping outward and downward through the till and the unsaturated silt beneath, could eventually flow laterally through saturated silt to Buttermilk Creek. It is possible that part of the water may continue downward, but this has not been verified because heads within the thick sequence of glacial deposits beneath the lacustrine unit are largely unknown. 


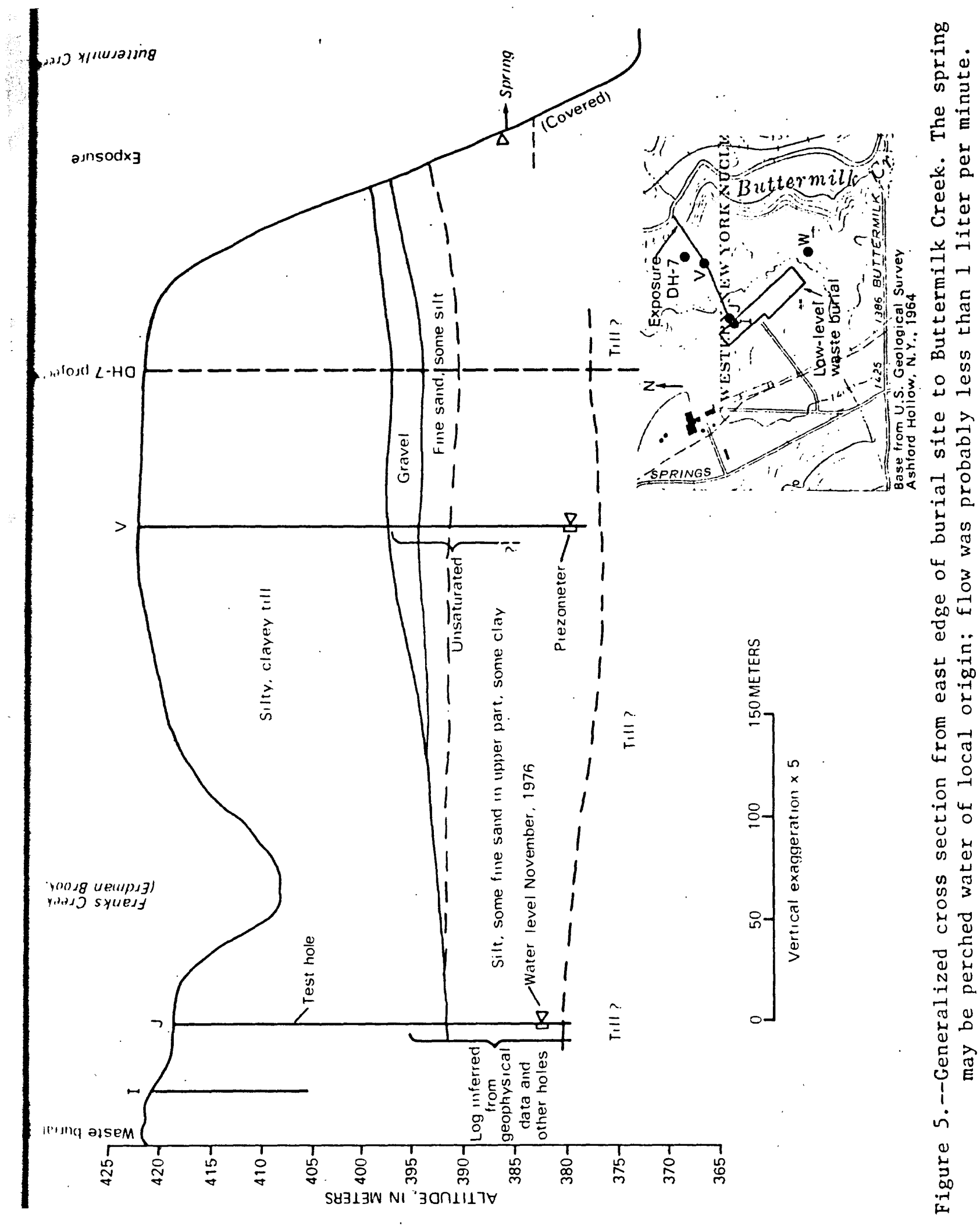


A finite-element digital model developed by Reeves and Duguid (1975) has been used to gain insight into the factors controlling the ground-water flow system near the burial ground. The modeling effort has been directed toward simulating the cross section in figure 3 as a steady-state system with the following assumed conditions:

(1) No-flow boundaries on either side of the section, inasmuch as the hydraulic gradient is vertical;

(2) In general, zero head at the base of the till, representing unsaturated conditions in the underlying silt;

(3) Steady rainfall, generally sufficient to saturate the till to land surface, but smaller in a few model runs so as to create local unsaturated conditions;

(4) Horizontal hydraulic conductivity of $1 \times 10^{-7} \mathrm{~cm} / \mathrm{s}$ for unweathered till, based on results of slug tests;

(5) Constant head of water within the trenches, equal to observed head in February 1976.

Model runs were made simulating either one or two geologic layers and simulating varying degrees of anisotropy in each layer. The difference between simulated pressure heads and those observed at piezometers in February 1976 was least when the model included two layers, the upper layer (which corresponded in thickness to the distance from land surface to the base of the oxidized fractures) being 10 times more permeable than the lower layer, and both layers being anisotropic with a 100:1 ratio of horizontal to vertical hydraulic conductivity. Simulating the upper layer as more permeable than the unweathered till is consistent with the presence of fractures and root tubes near land surface, and also with results of studies elsewhere (Grisak and Cherry, 1975) that showed that fractures in till significantly increase its permeability. However, the indication of strong anisotropy in the unweathered till seems inconsistent with the lack of regular stratification and the lack of evidence for widespread horizontal migration of water from the trenches (discussed in section "Subsurface migration of radioisotopes"). Results to date are preliminary; additional data and further trial simulations are needed to refine the model.

\section{RECHARGE TO THE TRENCHES}

Water levels in the trenches have been monitored regularly since 1966 by Nuclear Fuel Services, the company that has operated the burial ground. Figure 6, based largely on their data and compiled in part by E. J. Michaels (written commun., 1974), shows that most trenches exhibited a modest water-level rise shortly after each was completed and that water levels began to rise again in late 1971 in the older trenches, located at the north end of the burial ground (fig. 1). Trenches 3, 4, and 5 showed 


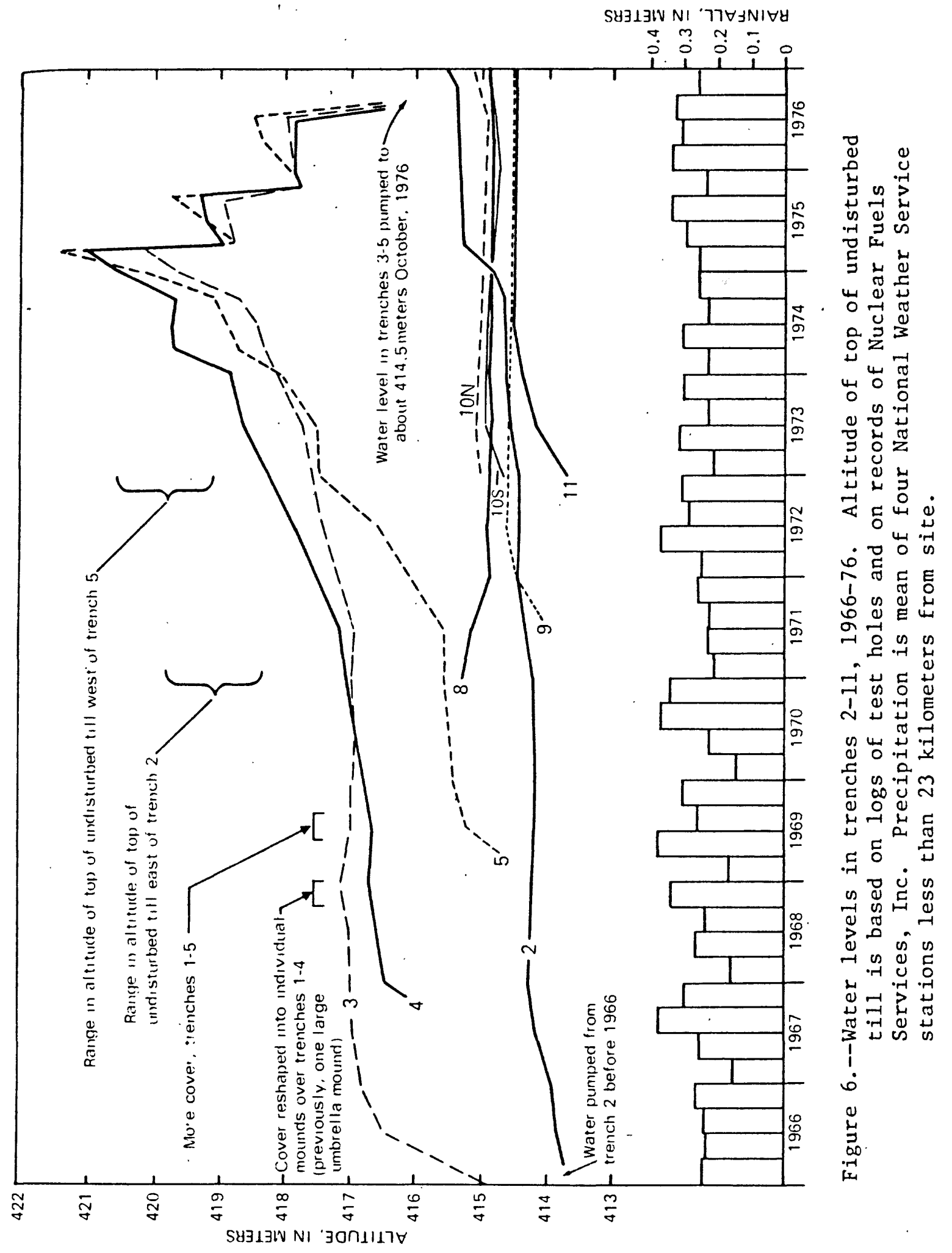


remarkably rapid rates of rise after 1971, with net rises for July to December generally equaling or exceeding those from January to June. (In contrast, records from wells and streams in western New York normally show the largest rises and peak stages in the spring.) In 1974, water in trenches 3, 4, and 5 rose into the reworked till used as cover over the trenches, and, in March 1975, trench water seeped out through the cover along the west side of trench 5 and the north end of trench 4 . Subsequently, much of the water in these three trenches was removed by pumping.

Water-level recorders have been maintained for several months on the sumps in trenches 3 and 5 to measure water-level changes in the trenches for comparison with precipitation. The hydrographs were complicated by frequent water-level fluctuations of as much as 8 centimeters in response to fluctuations in atmospheric pressure. The hydrograph from trench 5 for May-September 1975 has been corrected to a constant atmospheric pressure, resulting in the upper curve in figure 7. The lower curve represents cumulative precipitation recorded 340 meters away for the same period. The relation between the two curves changed during the summer. From May 31 to July 1 , the water level rose almost continuously but showed little correlation with rainfall events. From July 1 to July 31 , the water level rose principally during rainfall, with about 1 centimeter of water-level rise for each centimeter of rainfall. From August 1 to September 11 , the rise in water level during major rainfall was much larger (about 2 centimeters water-level rise for each centimeter of rainfall). September 12-20 was a period of frequent but light rainfall during which water level rose fairly steadily.

Two features of the hydrograph in figure 6 deserve explanation--the exact equivalence between periods of water-level rise and rainfall after July 1 , and the greater rate of rise in late summer. The most plausible explanation for the prompt response of trench-water levels to rainfall after July 1 is that one or more sets of cracks captured water flowing across the trench cover and transmitted that water immediately into the trench. Cracks are visible atop and alongside the trenches--both parallel and transverse to the trench axis--and the long rainless period in late June may have favored enlargement of cracks near land surface by dessication. The modest water-level rise and its poor correlation with rainfall in May and early June suggests that during periods of frequent rainfall, the cracks nearly close and thus reduce the rate at which water can enter the trench. Direct evidence of the significant role of cracks was obtained by siphoning water from a metal barrel into several sets of cracks on the north trenches. Commonly, water began to issue from a nearby lower crack after a few minutes at approximately the rate of input. However, on September 15 and 16, 1975, a total of 2,000 liters of water was siphoned into two sets of cracks atop trenches 4 and 5 without producing any surface outflow, which strongly suggests that these particular cracks opened downward into the trenches. 


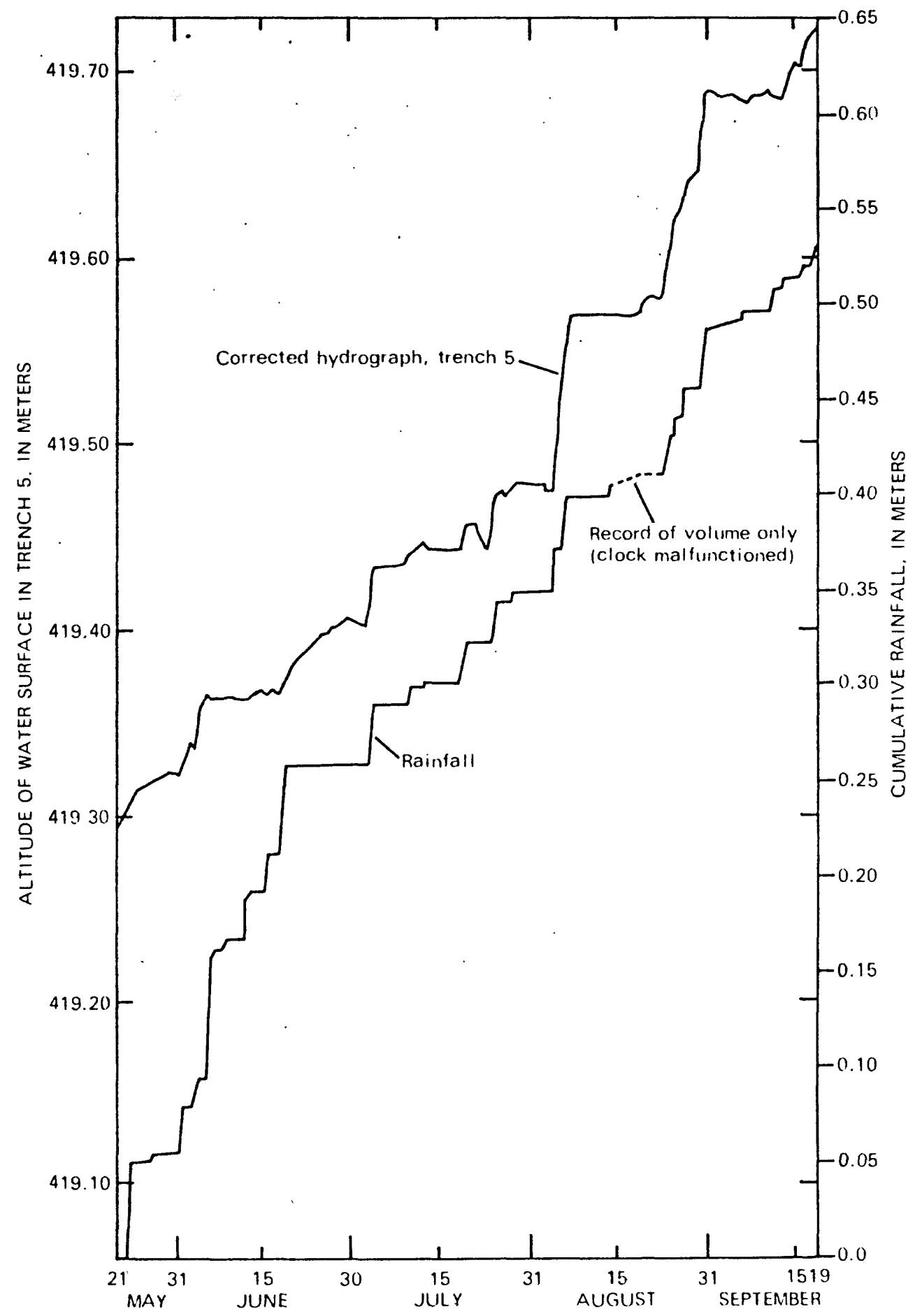

Figure 7.--Changes in water level in trench 5 compared with precipitation, May-September 1975. 
The greater rate of water-level rise relative to rainfall in the latter part of the summer could be due to a greater percentage of rainfall reaching the trench, along cracks that became enlarged by dessication during the summer and (or) by. collapse of decaying refuse at depth. Alternatively, the greater rate could be due to rise of the trench water through the top of the refuse into the cover, where the percentage of large, open voids would be much smaller and therefore any particular volume of recharge would more quickly fill the space available for it. Several lines of evidence suggest that the latter explanation is possible. Test holes west of trench 5 intersected the base of the cover at 419 to 420.5 meters in altitude (fig. 6 ), and well points driven through the cover into trench 5 exhibited a change in driving characteristics at about 419.5 meters. Furthermore, barometric efficiency (ratio of change in trench-water level, as measured in wells, to corresponding change in barometric pressure) for trench 5 increased 8 to 10 percent when trench water rose above that altitude (fig. 8)--which might be expected if the rising water had filled most space within the refuse. Changes in barometric pressure are probably transmitted through the cover by flow of air through a few cracks; large, interconnected void spaces above the trench water would further transmit pressure changes rapidly across the water surface (Gilliland, 1969, p. 244), thereby lowering barometric efficiency.

The direct evidence for recharge through cracks (described above), the history of rising water levels throughout the year, the continued rise of water levels above the base of the cover in 1974 and 1975, and the distribution of subsurface pressure heads (fig. 3 ) indicate that, at least since 1971, infiltration through the cover has been the predominant or sole source of recharge to trenches $3-5$.

Water levels in the newer trenches at the south end of the burial ground have changed little in recent years (fig. 6), except for trench 14, where a rise of about 50 centimeters has been recorded since completion of the trench in 1975. Continuous hydrographs from trenches 8, 9, and 14 (obtained for only a few months thus far) show no response to rainfall and generally negligible barometric efficiency. If infiltration through the cover of these trenches were comparable to the rates in trenches 3, 4, and 5, the observed low, stable water levels might be explained by assuming the till beneath the south trenches to be more permeable than that to the north. This seems unlikely at present, however, because (1) study of cores and slug tests in two piezometers near the south trenches did not suggest higher permeability, and (2) the lack of occasional temporary water-level rises in hydrographs available thus far from the south trenches argues against a potential for rapid infiltration. Minimal infiltration through the cover of the south trenches seems more likely and could be attributed to the lesser age and improved construction of these trenches. Specifically, there has 

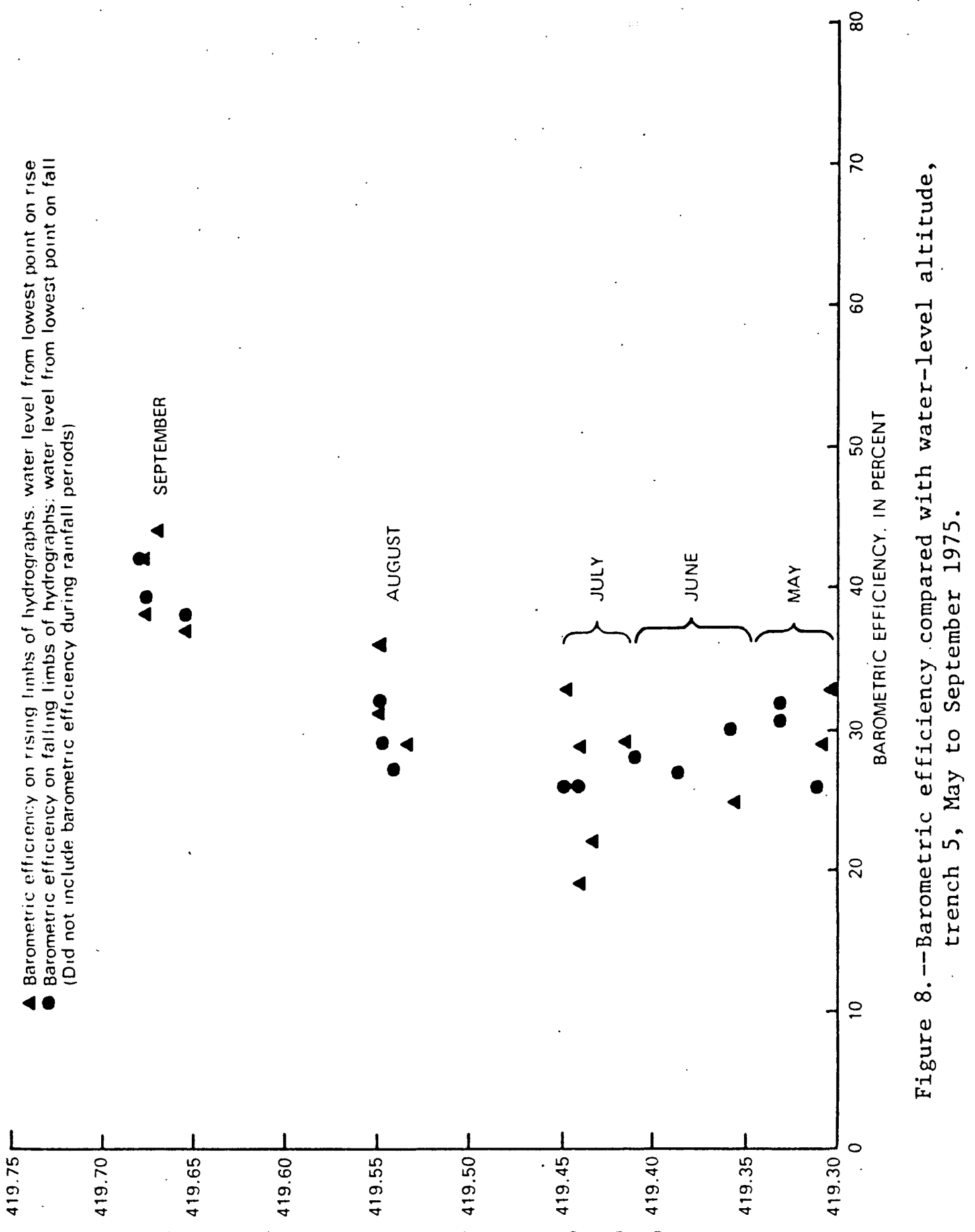

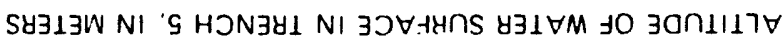


been less time for decay and settling of waste in the newer trenches to disrupt the cover, and design thickness of the cover was greater for the south trenches than for the others (Giardina and others, 1976, p. 13, 19). Also, although the cover of each trench except 5 and 14 . was compacted by temporarily piling on it the material excavated from the next trench, at the south trenches this procedure was required by permit and, according to Kelleher (in press), was more consistently practiced than at the north trenches. Kelleher reports that removal of soil and some weathered till before trench excavation was also required in the south part of the burial ground and was given more attention there than had been the case in the north part. Study of the rates of air movement through the trench cover is planned for 1977 to determine whether differences in cover permeability among the trenches can be detected.

\section{SUBSURFACE MIGRATION OF RADIOISOTOPES}

A total of 250 cores from the 1975 test drilling, mostly from holes within 5 meters of nominal trench boundaries, were analyzed for tritium by the Radiological Sciences Laboratory of the New York State Department of Health by procedures described by Matuszek and others (1976, p. 363). Drilling and sample-handling procedures were designed to ensure that cores sent to the laboratory would not be contaminated with water or sediment derived from other than the nominal depth. The holes were drilled with a combination air-rotary/cable-tool rig; in general, 8-inch or 6-inch casing was driven to the bottom of the hole after every 3 to 5 meters of drilling, or more often if a flow of water into the hole was detected. Drill cuttings were blown out entirely by air pressure for the first 6 to 12 meters of each hole; at greater depths, a small amount of water was injected into the air stream during drilling, after which air was circulated without water for several minutes to dry the bottom, of the hole before coring. Most cores were obtained with a Denison $1 /$ core barrel held so that it could not scrape the sides of the hole. it was equipped with fresh liners for each interval cored and was generally pushed into the till without rotation or air circulation. After each core was removed from its liners, it was cut into segments. The outer 1 or 2. millimeters of the core, which had become smeared as a result of drag as the core was forced into the core barrel, was trimmed off with a clean knife. Each trimmed core segment was handled with disposable gloves, placed in a plastic bag, and sealed in a glass jar. Most cores from below 9 meters were trimmed in a glove box that contained a drying agent and was flushed with bottled nitrogen to prevent interchange with atmospheric water vapor in case the cores contained "old" water with less tritium than ambient air.

$1 /$ Use of the brand name in this report is for identification purposes only and does not imply endorsement by the U.S. Geological Survey. 
Results of tritium analyses are summarized in figures 9-13. In nearly all holes, peak tritium concentrations were in the range of $1 \times 10^{-3}$ to $1 \times 10^{-5}$ microcuries per milliliter $(\mu \mathrm{Ci} / \mathrm{mL}$ ) and were found near land surface, generally within the reworked till used to cover the vicinity of the trenches. In holes $D$ and $E$, peak tritium concentrations were as high as $6 \times 10^{-2}$ and $3 \times 10^{-1} \mu \mathrm{Ci} / \mathrm{mL}$, respectively; these concentrations were in cores from (or adjacent to) permeable sandy layers in backfill that lay below the water level in adjacent trench 5 at the time of drilling and below the level of the top of the undisturbed till farther from the trench (fig. 14). Holes $D$ and $E$ are in an area where seepage from trench 5 reached land surface in March 1975. The water level in the sandy backfill at hole $\mathrm{E}$ in September 1975 was within 4 centimeters of the water level in trench 5. It seems likely that the shallow tritium peaks in holes $D$ and $E$ represent water from trench 5 that migrated outward through the backfill, especially along sandy layers, during the period of high trench-water levels prior to March 1975.

Tritium concentrations generally declined rapidly with depth in the zone of oxidized fractures that underlies the weathered till. Tritium concentrations were generally less than $1 \times 10^{-6} \mu \mathrm{Ci} / \mathrm{mL}$ in the unaltered till below the oxidized fractures (that is, more than 4.5 to 6 meters below present land surface, or 3 to 4.5 meters below the top of undisturbed oxidized till). Holes $B, D$, and $E$, however, show a striking peak in tritium concentration below the zone of oxidized fractures. Each of these anomalies (1) is represented by more than one core, (2) exceeds a concentration of $1 \times 10^{-5} \mu \mathrm{Ci} / \mathrm{mL}$, and (3) exceeds by more than one order of magnitude other tritium concentrations at less depth in the same hole. Each anomaly lies at or below the reported bottom altitude of nearby trenches and, except in hole $\mathrm{E}$, each anomaly is centered where silt lenses were especially numerous in the cores. These characteristics suggest that the anomalies are due to outward and downward migration of tritium from the burial trenches, probably in part along lenses of silt whose permeability permitted more rapid flow and whose orientation may have favored lateral movement. Other irregularities in the vertical, profiles of tritium concentration were noted below the oxidized-fracture zone, and some may reflect the first arrival of tritium migrating from the trenches. For example, note that hole I3 (1 meter closer to trench 2 than hole I) had tritium concentrations consistently higher than those at hole $I$ at depths below the water level in trench 2 (fig. 11). However, most irregularities involved very low concentrations and unsystematic distribution and might be attributed to downward migration of precipitation with abnormal tritium from the era of nuclear-weapons testing, incidental contamination in field or laboratory sample handling, or instrumental counting irregularities that exceeded two standard errors.

The locations of holes $\mathrm{B}, \mathrm{D}$, and $\mathrm{E}$ with respect to inferred trench boundaries are shown in figure 14. The deep secondary tritium peaks in holes $D$ and $E$ suggest that tritium had migrated at least 2.5 meters from the trench. The secondary peak in hole B suggests a migration distance 


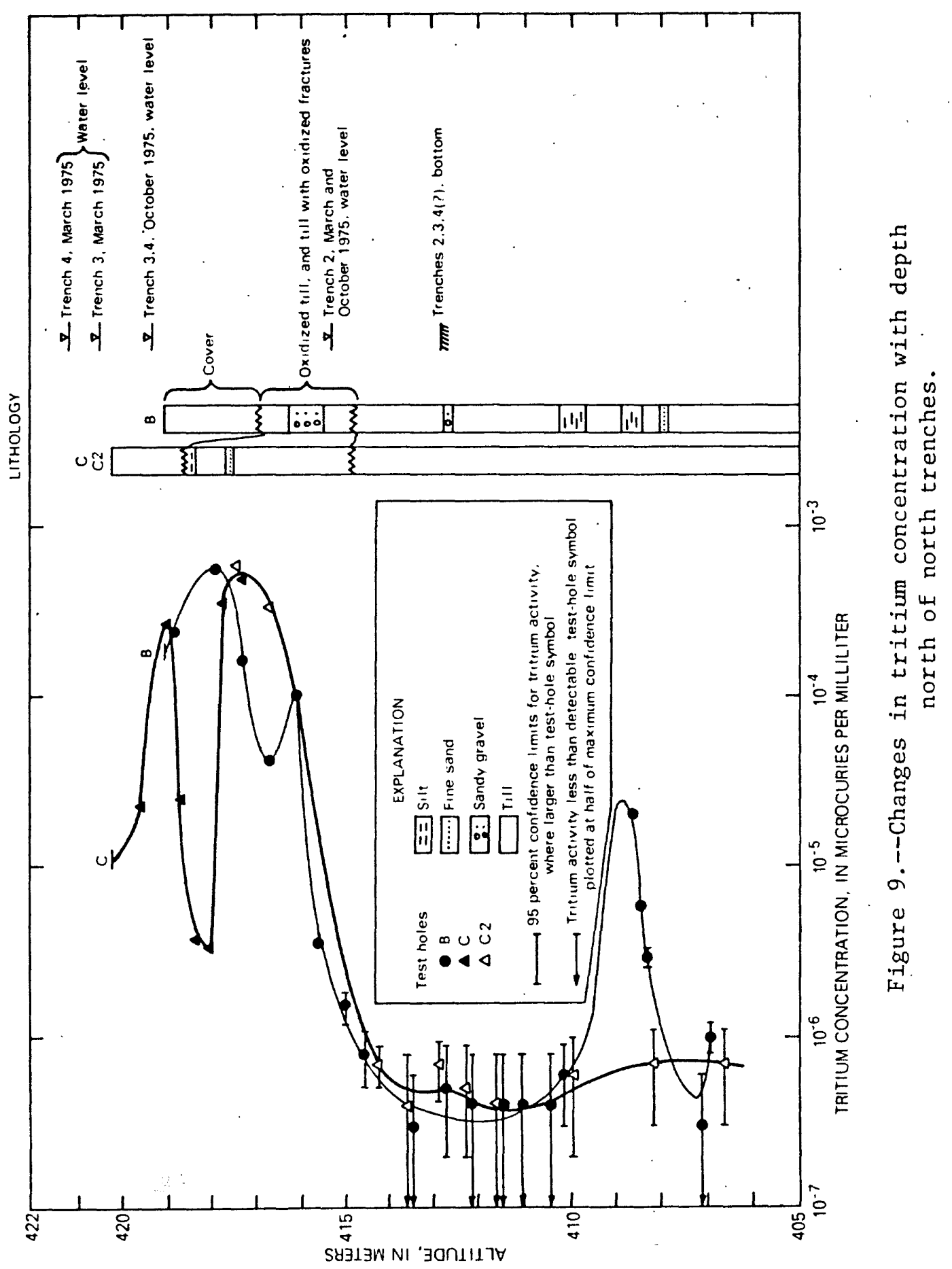




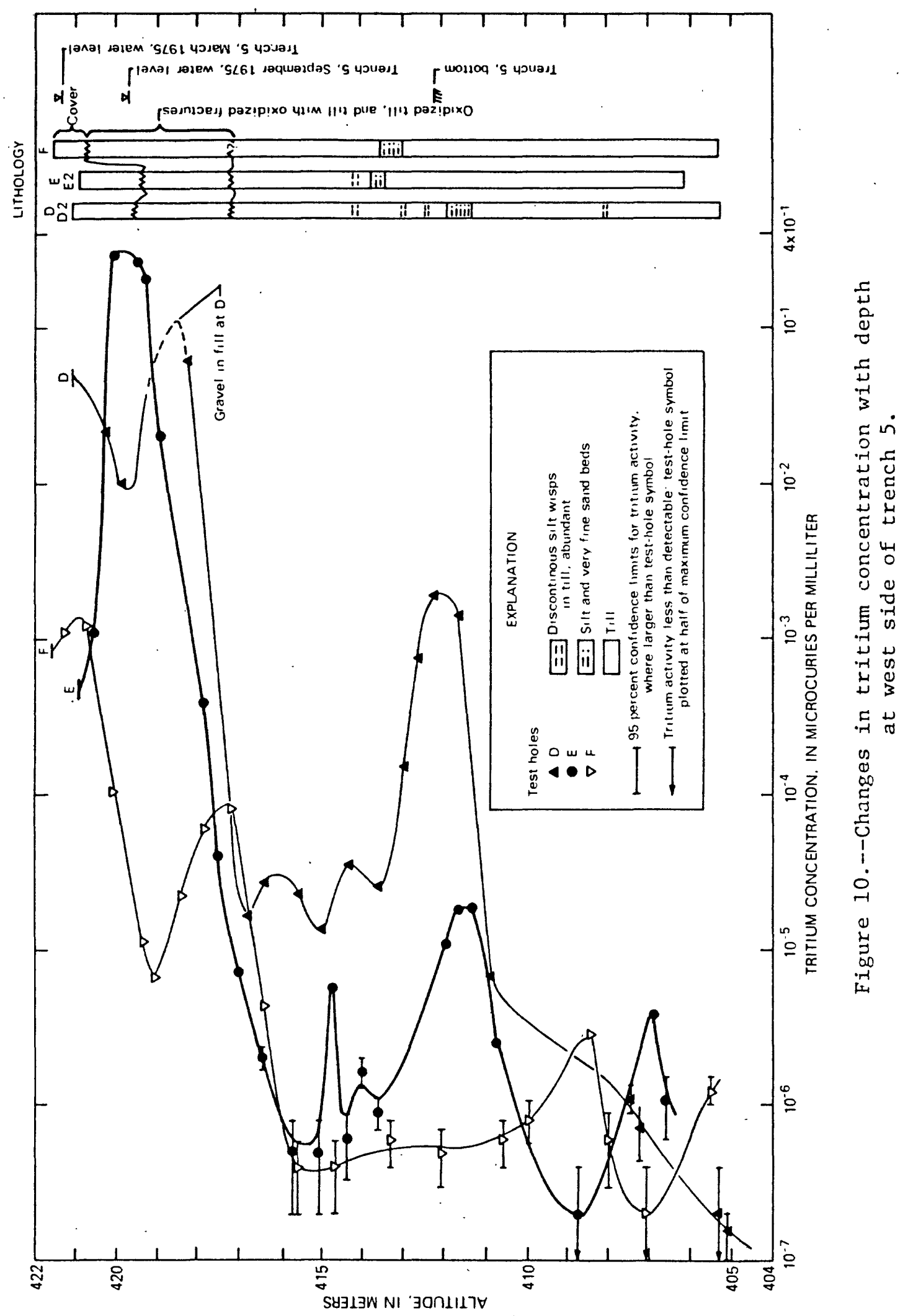




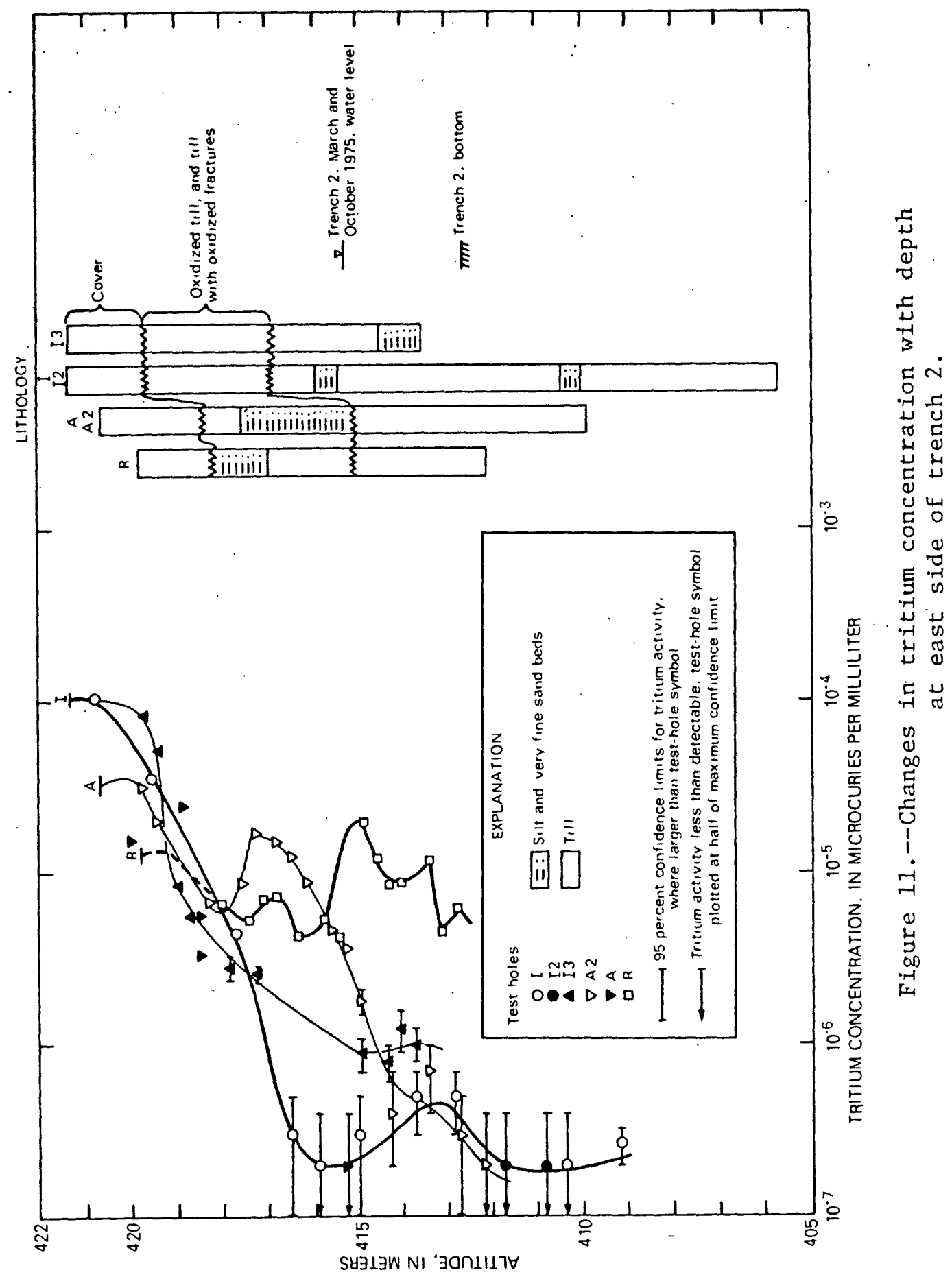




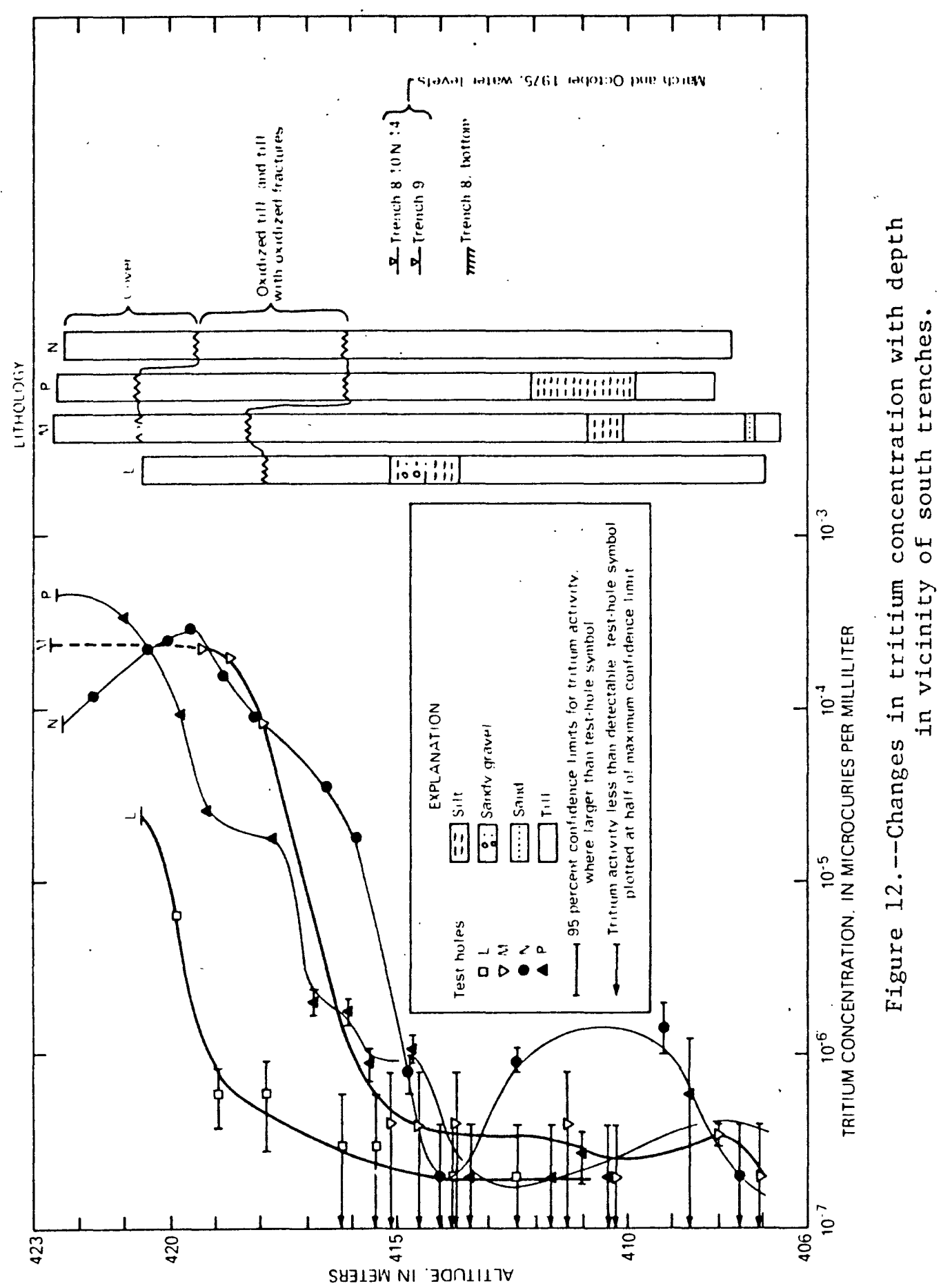




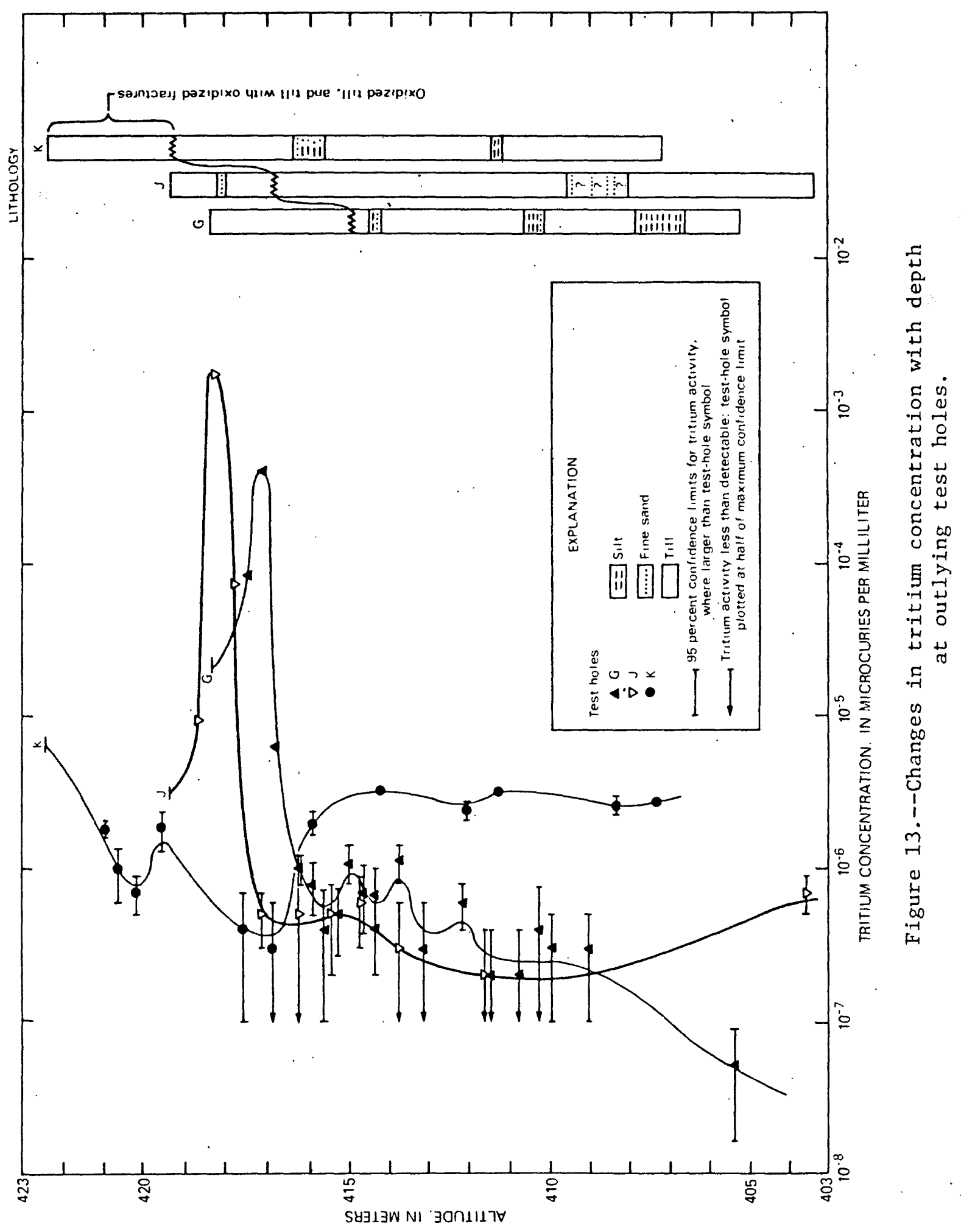


of at least 12 meters (if the assumed trench geometry shown in figure 14 is correct). About 2 meters west of hole $B$, a hole was drilled in 1973 in which cores were collected at 1.5-meter intervals; all cores between depths of 6 and 12 meters contained less than $1.8 \times 10^{-6} \mu \mathrm{Ci} / \mathrm{mL}$ tritium (Duckworth and others, 1974, hole 3). It may be that the tritium is restricted to a narrow silt lens that is present only at hole $B$ or was skipped by the cores in hole 3. Also, hole 3 was an auger hole that was allowed to collapse upon completion, and it is remotely possible that this abandoned hole has become an avenue of vertical migration from contaminated soil near land surface.

Some information on distribution of radioisotopes other than tritium is available from holes near the burial trenches. For example, a few cores from the 1975 test holes received detailed laboratory analysis, as summarized in table 1 . The cores analyzed may be grouped into three classes, characterized as follows:

1) Cores constituting a vertical profile below land surface in hole F. Individual isotopes were generally below detection limits except at the shallowest depth.

2) Cores containing secondary peak tritium concentrations some distance below land surface, including the striking tritium anomalies in holes $\mathrm{B}, \mathrm{D}$, and $\mathrm{E}$. Individual isotopes were generally below detection limits except for naturally occurring isotopes of uranium.

3) Cores containing oxidized fractures. The objective and results of these analyses are discussed subsequently.

Geophysical logging provided additional information on distribution of gamma-emitting isotopes. The U.S. Geological Survey logged holes C2, $E, D 2, I, J, M, N$, and $P$, generally through steel tubes installed for this purpose. The usual procedure was to run continuous neutron and gross gamma logs, then to obtain in-hole gamma spectra at depths where gross gamma was highest and to "strip" those spectra as described by Eggers (1976). Artificial isotopes were detected in three or perhaps four holes (W. S. Keys, written commun., 1976) but only in narrow depth intervals within or at the base of the cover material (table 2).

Cores were collected in 1973-74 from holes augered near the trenches (holes 1-10, fig. 1) as part of an earlier study (Duckworth and others, 1974). Results of radiometric analyses of these cores were presented by Matuszek and others (1976), who pointed out that concentrations of tritium peaked between 1 and 3 meters below land surface and that other radioisotopes peaked very close to land surface. They concluded that, although lateral migration from the trenches is a possible explanation for these shallow peaks at some locations, contamination at other locations was entirely above historical water levels in nearby trenches and that the best explanation would therefore be some combination of surface processes 


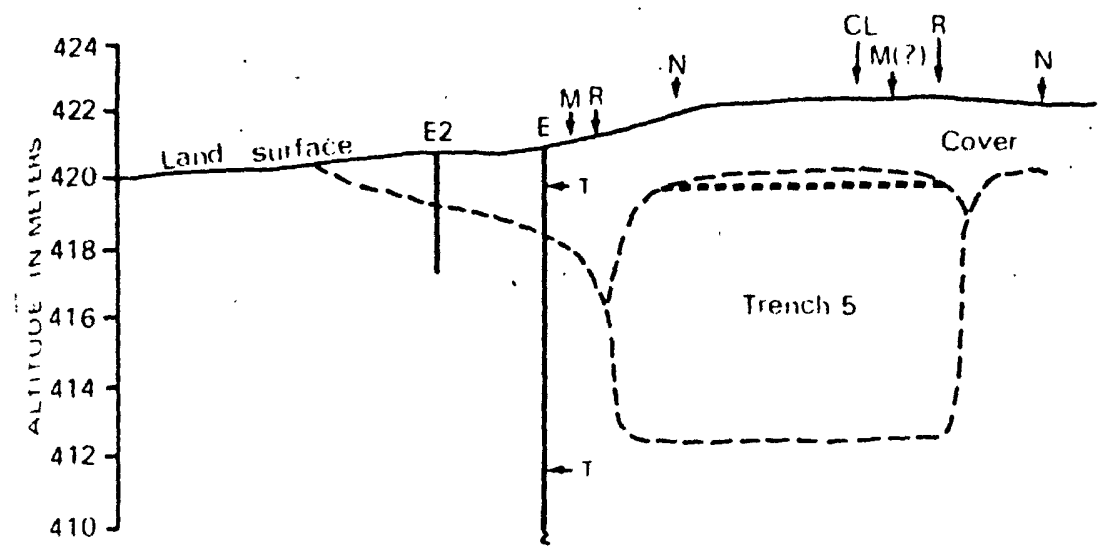

EXPLANATION

$\mathrm{Cl}$

Nommal trench center line (between monuments)

Nommal position of trench wall. from specifications

$R$

Position of trench wall suggested by resistivity

$M$

Pusition of tiench walt suggested

by machnetomete: data

17.5 meters north and south)

\section{$P$}

Position of trench wall (nea bottom

pojected from 1974 sliant hole 12

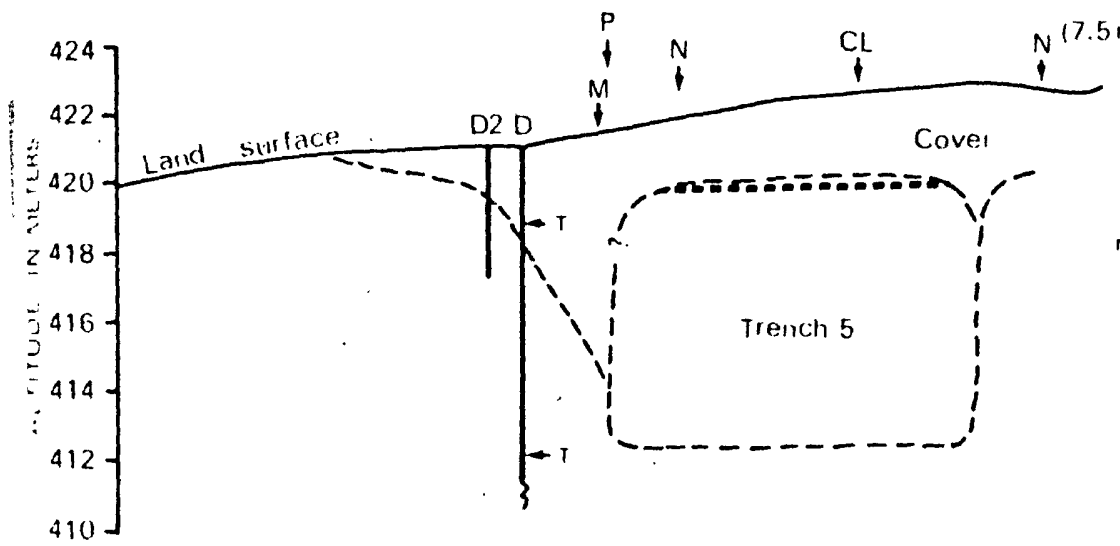

B. D. D2, E, E2

Test holes, loys avallable

$$
\text { - - - - }
$$

Inferred contact between cover material, undisturbed till. and refuse

\section{-anome}

Water level in trench

Peak or secontiary peak tritium concentration in cores

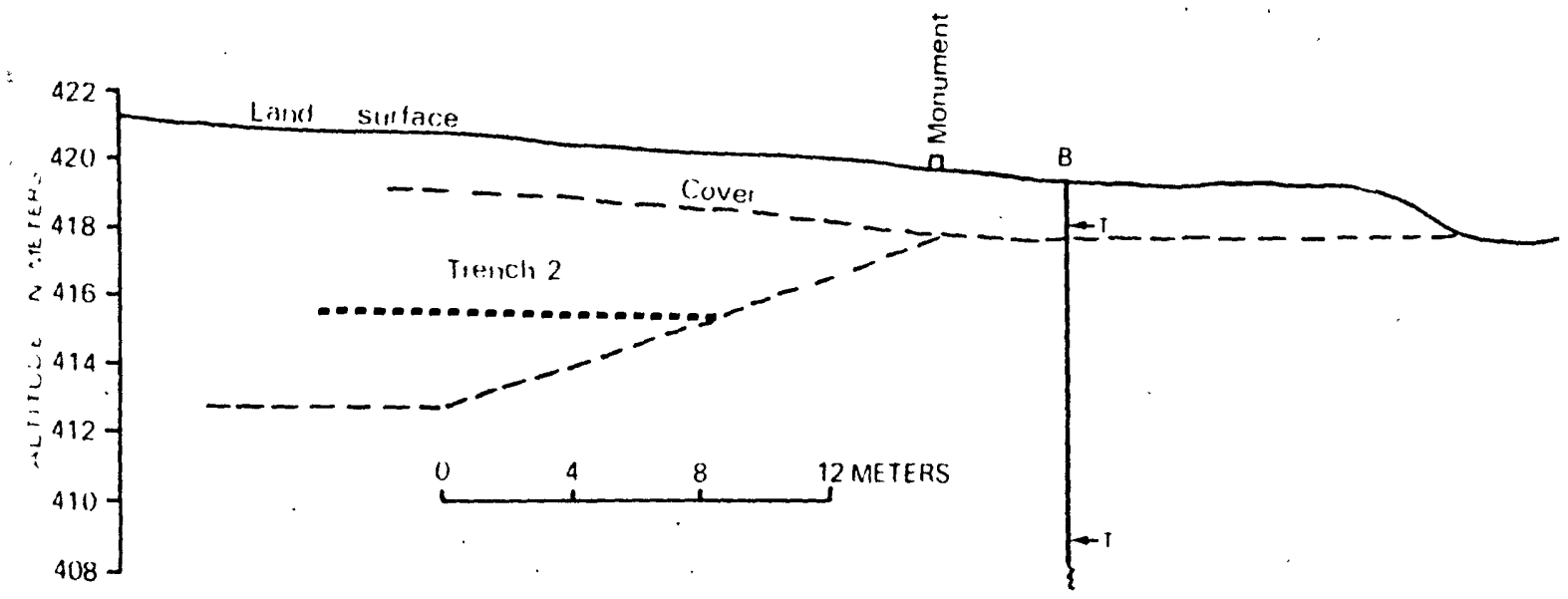

Figure 14.--Detailed cross sections through holes $B, D$, and E. 


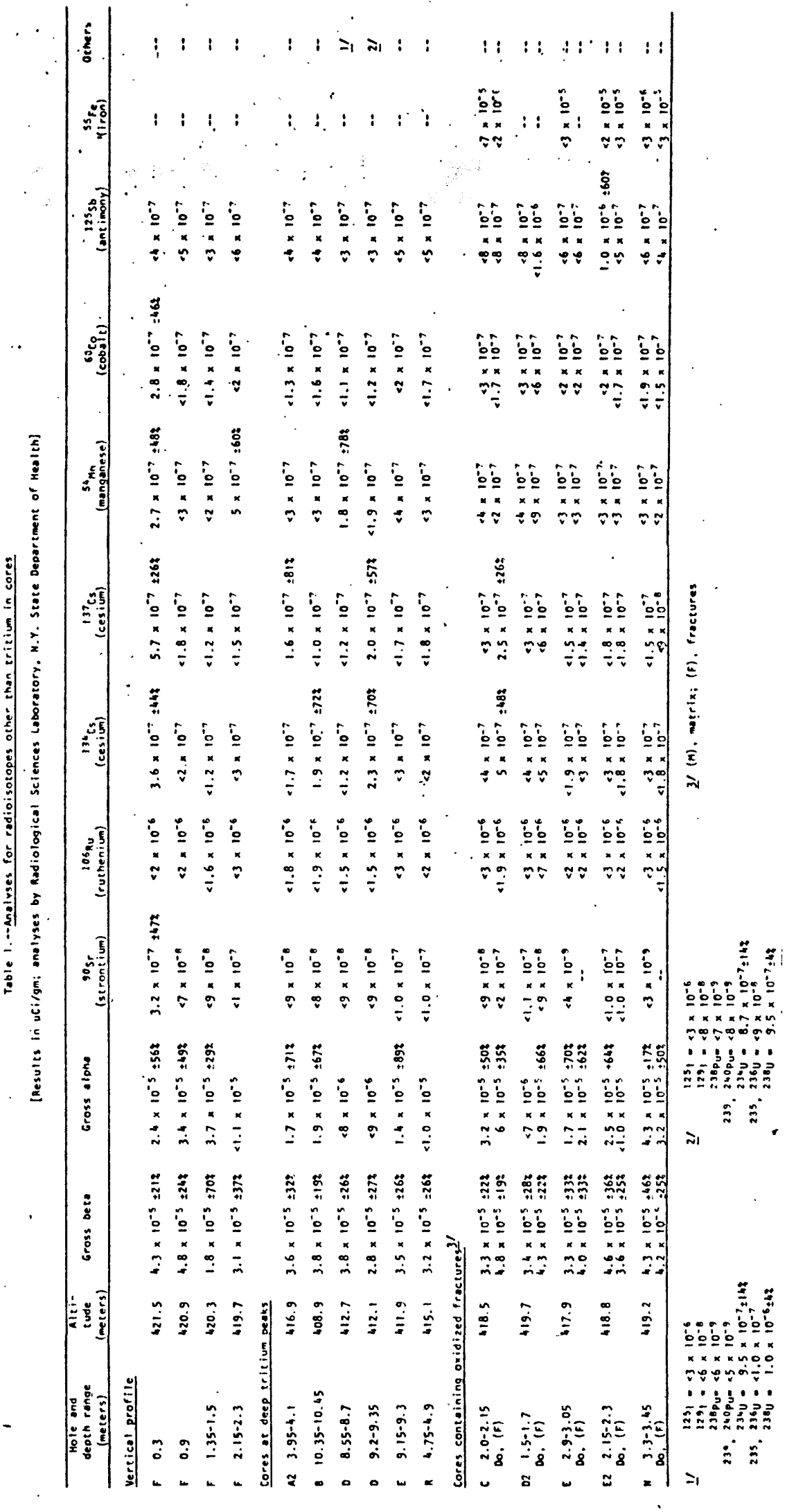


Table 2.--Preliminary results of in-hole gamma spectral logging

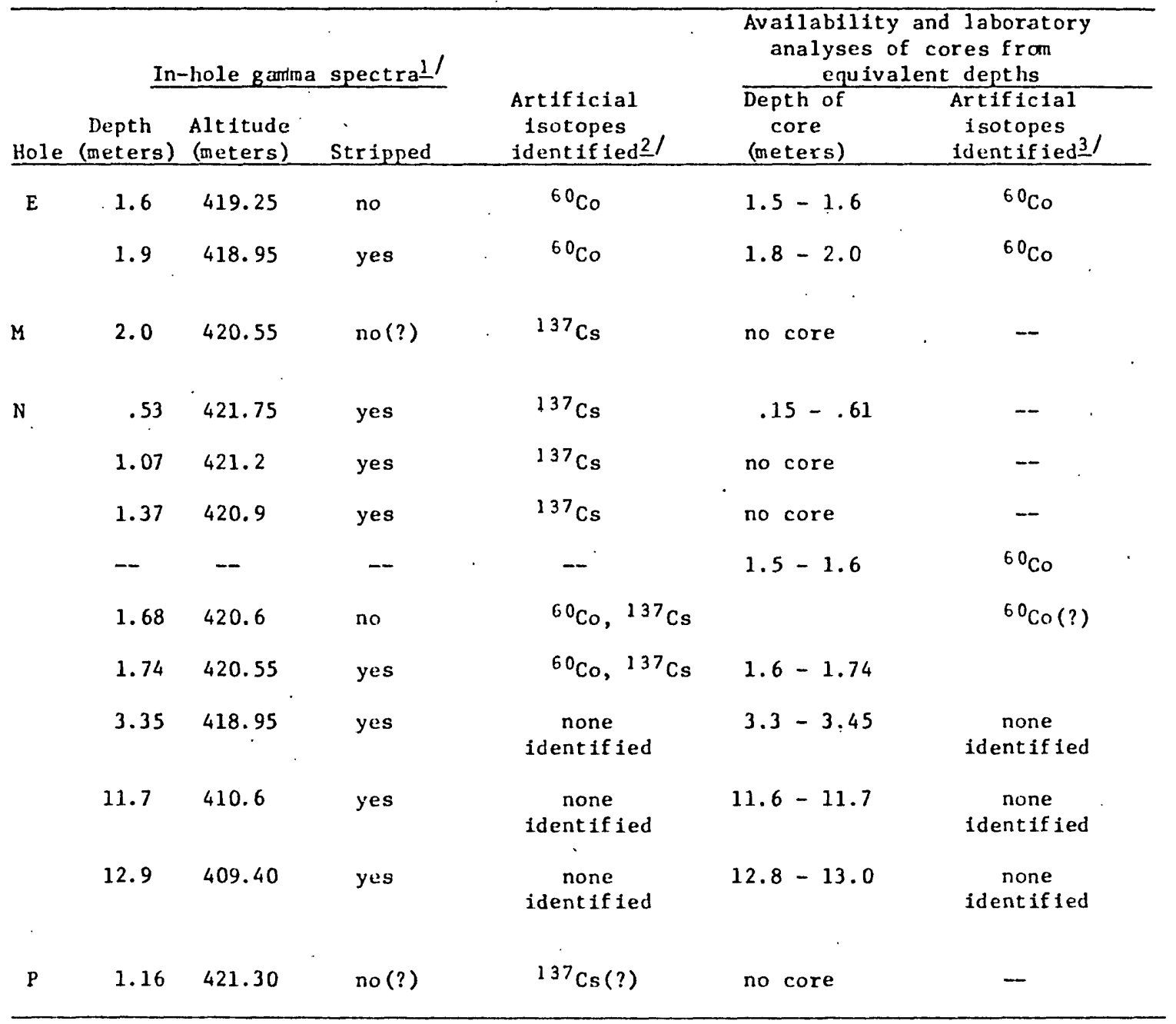

1-/ W. S. Keys, U.S. Geol. Survey, written commun., 1976. Other in-hole spectra were neasured but have not yet been stripped; no contamination was recognized prior to stripping.

2/ Co, Cobalt; Cs, Cesium.

$3 /$ C. M. Bunker and C. A. Bush, U.S. Geo1. Survey, written commun., 1976 
such as (1) spills during emplacement of refuse or during removal of excess water from trenches during construction, (2) redistribution of water by excavation equipment that entered the trenches, and (3) fallout from the stack at the nearby fuel-reprocessing plant. Data from the present study support their conclusions; peak values of tritium from holes in the south burial area and holes bordering the east side of trench 2 were obtained above the highest water levels recorded in adjacent trenches (figs. 11, 12).

As previously noted, tritium concentrations in nearly every hole were highest within the reworked cover material or oxidized till. They declined in the underlying zone of oxidized fractures and root tubes and were low in the unaltered till below. This distribution could be interpreted as a function of higher permeability in the upper layers due to the fractures and root tubes or as simply a function of time and slow downward migration. Five cores in which prominent oxidized fractures cut through unaltered till were specially processed in an effort to find evidence of radioisotope movement along fractures. Several grams of chemically altered till along the inner face of the fracture were trimmed into a glass vial and sealed; the remainder of the altered till was trimmed away, and the remaining unaltered matrix was sealed in a glass jar in the usual manner. Four of the five cores were near places where the trenches had overflowed in early 1975; thus, the materials cored could conceivably have been in the path of lateral migration or vertical infiltration of water originating in the trenches in 1975, as well as having been exposed to infiltration of fallout and other surface contamination over the years. Fracture trimmings and unaltered matrix were both analyzed for a variety of isotopes because if elevated concentrations of isotopes could be detected in the fracture trimmings, preferential movement of water along the fractures and sorption along fracture walls would be indicated. However, all individual isotopes sought (table 1) were below detection limits in both fracture trimmings and matrix in almost every case, and gross alpha and gross beta determinations on fracture trimmings were nearly identical (within two standard errors) to those on matrix samples. Thus, this experiment provides no support for the concept of fracture permeability being a major factor in isotope migration.

\section{A PROVISIONAL PERSPECTIVE ON THE HYDROLOGY}

Most precipitation on the burial site returns to the atmosphere by evapotranspiration or quickly runs off to streams as overland sheet flow, in gullies, and through networks of shallow, interlaced mole runs. The little water that infiltrates beyond the roots of plants moves generally downward, even beneath small valleys bordering the site. Pressure heads within the till range from near zero to several meters. Small heads seem to occur where steep, smooth slopes or stripping of soil encourage rapid, complete runoff; larger heads are present where water accumulates above 
the till, most notably in the north burial trenches, but also in natural depressions in the land surface (such as near holes J and K, fig. 1) and in remnants of late-glacial fluvial gravel atop the till.

Cores from test borings drilled in 1973 and 19753 to 5 meters from the trenches indicate that in only a very few places has trench water migrated that far outward (laterally) over the 5 to 11 years since trench completion. Piezometers indicate that hydraulic gradients near the trenches are predominantly downward, with only a small outward component (figs. 3, 4). If the till were nearly isotropic, subsurface flow originating in partly saturated trenches would not intersect stream valleys bordering the site. However, some observations and calculations suggest that anisotropy within the till and secondary permeability at shallow depth may significantly favor lateral subsurface flow. The questions of whether a lateral flow component could carry trench water to the valley of Erdman Brook or its tributaries and, if so, how long this would take, have not yet been resolved. Simple calculations based on Darcy's Law, hydraulic conductivity of $1 \times 10^{-7} \mathrm{~cm} / \mathrm{s}$ for the till and $1 \times 10^{-2} \mathrm{~cm} / \mathrm{s}$ for the underlying silt, and a porosity of 0.25 suggest that water moving downward from the trenches would take at least 160 years to reach the silt and at least another 250 years to move laterally through the silt to Buttermilk Creek. Any anisotropy in the till would increase travel time, as would any interaction with earth materials by isotopes other than tritium.

Experience and data available through 1976 demonstrate that under the conditions of abundant precipitation and poorly permeable till at West Valley, radioisotopes are far less likely to reach the environment by subsurface seepage than by saturation and overflow of the trenches, which can occur when there is substantial recharge through cracks in the cover. 


\section{References Cited}

Cooper, H. H., Jr., Bredehoeft, J. D., and Papadopulos, S. S., 1967, "Response of a finite-diameter well to an instantaneous charge of water," Water Resources Research, 3, 263.

Duckworth, J. P., Jump, M. J., and Knight, B. E., 1974, "Low level radioactive waste management research project--final report," West Valley, N.Y.," Nuclear Fuels Services, Inc., 57 p.

Eggers, D. E., 1976, "The application of borehole geophysics to the selection and monitoring of nuclear waste disposal sites," Rock Mechanics Symposium, 17th, Snowbird, Utah, preprint, 7 p.

Giardina, P. A., De Bonis, M. F., and Eng, J., undated [1976], "Summary report on the low-level radioactive waste burial site, West Valley, New York (1963-1975)," New York, N.Y., U.S. Environmental Protection Agency, Region II, 139 p.

Gilliland, J. A., 1969, "A rigid plate model of the barometric effects," Jour. Hydrology, 7, 233.

Grisak, G. E., and Cherry, J. A., 1975, "Hydrologic characteristics and response of fractured till and clay confining a shallow aquifer," Canadian Geotech. Jour., 12, 23.

Kelleher, W. J., "Water problems at the West Valley site," in Carter, M. W., Kahn, B., and Moghissi, A. A. (eds.), 1977, Management of low-level radioactive waste: Atlanta, Georgia Institute of Technology (in press).

Matuszek, J. M., Strnisa, F. V., and Baxter, C. F., 1976, "Radionuclide dynamics and health implications for the New York Nuclear Service Center's radioactive waste burial site," Vienna, Austria, Internat. Atomic Energy Agency, IAEA-SM-207/59, p. 359-372.

Pferd, J. W., Fakundiny, R. H., and Davis, J. F., "Geology and integrity of low-level waste-burial trenches at West Valley, New York," in Carter, M. W., Kahn, B., and Moghissi, A. A. (eds.), 1977, Management of low-level radioactive waste: Atlanta, Georgia Institute of Technology (in press).

Reeves, M., and Duguid, J. 0., 1975, "Water movement through saturatedunsaturated porous media--a finite-element Galerkin model," Oak Ridge, Tenn., Oak Ridge Nat1. Lab., ORNL-4927, 232 p. 